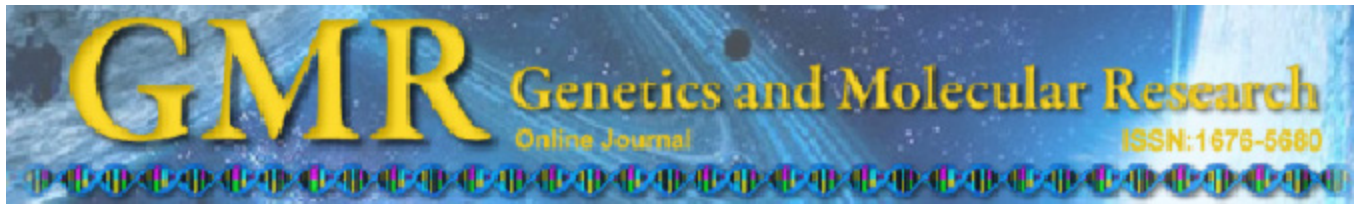

\title{
Microbial community and performance of slaughterhouse wastewater treatment filters
}

\author{
M.I. Stets ${ }^{1,2}$, R.M. Etto ${ }^{3}$, C.W. Galvão ${ }^{4}$, R.A. Ayub ${ }^{5}$, L.M. Cruz ${ }^{2}$, \\ M.B.R. Steffens ${ }^{2}$ and A.C. Barana ${ }^{1}$ \\ ${ }^{1}$ Departamento de Engenharia de Alimentos, \\ Universidade Estadual de Ponta Grossa, Ponta Grossa, PR, Brasil \\ ${ }^{2}$ Núcleo de Fixação Biológica de Nitrogênio, \\ Departamento de Bioquímica e Biologia Molecular, \\ Universidade Federal do Paraná, Curitiba, PR, Brasil \\ ${ }^{3}$ Laboratório de Biologia Molecular Microbiana, \\ Departamento de Química, Universidade Estadual de Ponta Grossa, \\ Ponta Grossa, PR, Brasil \\ ${ }^{4}$ Laboratório de Biologia Molecular Microbiana, \\ Departamento de Biologia Estrutural, Molecular e Genética, \\ Universidade Estadual de Ponta Grossa, Ponta Grossa, PR, Brasil \\ ${ }^{5}$ Laboratório de Biotecnologia Vegetal, \\ Departamento de Fitotecnia e Fitossanidade, \\ Universidade Estadual de Ponta Grossa, Ponta Grossa, PR, Brasil \\ Corresponding author: C.W. Galvão \\ E-mail: carolinawgalvao@hotmail.com
}

Genet. Mol. Res. 13 (2): 4444-4455 (2014)

Received April 29, 2013

Accepted May 26, 2014

Published June 16, 2014

DOI http://dx.doi.org/10.4238/2014.June.16.3

\begin{abstract}
The performance of anaerobic filter bioreactors (AFs) is influenced by the composition of the substrate, support medium, and the microbial species present in the sludge. In this study, the efficiency of a slaughterhouse effluent treatment using three AFs containing different support media was tested, and the microbial diversity was investigated by amplified ribosomal DNA restriction analysis and 16S rRNA gene sequencing. The physicochemical analysis of the AF systems tested
\end{abstract}


suggested their feasibility, with rates of chemical oxygen demand removal of $72 \pm 8 \%$ in hydraulic retention times of 1 day. Analysis of $\mathrm{pH}$, alkalinity, volatile acidity, total solids, total volatile solids, total Kjeldahl nitrogen, and the microbial community structures indicated high similarity among the three AFs. The composition of prokaryotic communities showed a prevalence of Proteobacteria $(27.3 \%)$ and Bacteroidetes (18.4\%) of the Bacteria domain and Methanomicrobiales (36.4\%) and Methanosarcinales $(35.3 \%)$ of the Archaea domain. Despite the high similarity of the microbial communities among the AFs, the reactor containing pieces of clay brick as a support medium presented the highest richness and diversity of bacterial and archaeal operational taxonomic units.

Key words: Anaerobic biodigestion; Support medium; 16S rRNA; Microbial community

\section{INTRODUCTION}

Slaughterhouses produce large quantities of wastewater containing high concentrations of organic matter, suspended solids, nitrogen, and phosphorus compounds; this wastewater requires treatment before being discarded into water bodies (Merzouki et al., 2005). One of the most successful methods for anaerobic digestion is microbial immobilization on an inert support medium (Tay and Show, 1998). Anaerobic filters are widely used to treat industrial effluents. However, choosing the correct support medium is extremely important to ensure the effectiveness of the reactor. Specific surface area, porosity, surface roughness, pore size, and orientation of the packing material play important roles in anaerobic filter reactor performance (Tay and Show, 1998).

The microbial community structure in anaerobic digesters also has attracted the interest of engineers because understanding microbial behavior is essential to improve the digestion process (Lee et al., 2008). Although microbial compositions of anaerobic reactors have been reported in the literature, there are few studies reporting the influence of the support medium on the community composition in upflow anaerobic filter (UAF) reactors (Tang et al., 2007).

In this study, we evaluated the efficiency of the treatment of slaughterhouse effluent using three UAFs containing different support media and determined the composition of the archaeal and bacterial communities of these UAFs using culture-independent 16S rRNA gene sequencing.

\section{MATERIAL AND METHODS}

\section{AF reactor}

The bench-scale UAF reactors were built with polyvinyl chloride $(30 \mathrm{~cm}$ in length and $10 \mathrm{~cm}$ in diameter) and were filled with different support media. Reactor A was filled with a usually used material in our lab, polypropylene rings (Beux et al., 2007); reactor B was filled with a promising support material described in the literature, polyurethane foam (Silva et al., 
2006; Rodriguez and Zaiat, 2011); and reactor C was filled with a cheap alternative taken from construction debris, clay brick. Biogas produced from the reactor was observed by the water displacement method. Details of the support material used in the experiments are in Table 1.

\begin{tabular}{|c|c|c|c|}
\hline & Polypropylene rings & Polyurethane foam & Clay brick \\
\hline Dimensions & $\begin{array}{l}0.8 \mathrm{~cm} \text { diameter, } 0.5 \mathrm{~cm} \text { length, } \\
\text { and } 0.1 \mathrm{~cm} \text { depth }\end{array}$ & Cubes with 0.5 -cm edges & Pieces selected by $3 / 4$ " sieve \\
\hline Apparent density $\left(\mathrm{g} / \mathrm{cm}^{3}\right)$ & 1.64 & 0.0014 & 1.66 \\
\hline Porosity (\%) & $\mathrm{Na}$ & $\mathrm{Na}$ & 37.93 \\
\hline
\end{tabular}

$\mathrm{Na}=$ not analyzed.

Wastewater generated from a Southern Brazil slaughterhouse $\left(25^{\circ} 05^{\prime} 14.58^{\prime \prime} \mathrm{S}\right.$ and $\left.50^{\circ} 06^{\prime} 22.76 \mathrm{\prime W}\right)$ that processed about 500 cattle and 2000 pigs per month was used as substrate. The physicochemical characteristics of slaughterhouse wastewater used in this study are in Table 2. Currently, the slaughterhouse wastewater contaminates the soil and rivers of the Brazilian Atlantic Rain Forest, one of the world's largest biodiversity hotspots. The inoculum used in the reactors was obtained from a methanogenic upflow anaerobic sludge blanket used to treat alcohol industry wastewaters in Southern Brazil $\left(25^{\circ} 09^{\prime} 44.29^{\prime \prime S}\right.$ and $\left.50^{\circ} 07^{\prime} 31.28^{\prime \prime} \mathrm{W}\right)$.

\begin{tabular}{lcc} 
Table 2. Physicochemical characteristics of slaughterhouse wastewater. & \\
\hline Parameter & Present study & Published \\
\hline $\mathrm{pH}$ & $6.95-8.81$ & $7.53-7.7^{\mathrm{a}}$ \\
Alkalinity $(\mathrm{mg} \mathrm{CaCO} / \mathrm{L})$ & $131-533$ & $218-324^{\mathrm{b}}$ \\
Volatile acidity $\left(\mathrm{mg} \mathrm{CH}_{3} \mathrm{COOH} / \mathrm{L}\right)$ & $102-259$ & - \\
Total solids $(\mathrm{mg} / \mathrm{L})$ & $50.8-166.2$ & $2,032-3,139^{\mathrm{b}}$ \\
Volatile solids $(\mathrm{mg} / \mathrm{L})$ & $45.6-118.6$ & $1,397-2,379^{\mathrm{b}}$ \\
Chemical oxygen demand $(\mathrm{mg} \mathrm{O} / \mathrm{L})$ & $962-3543$ & $7,148-20,400^{\mathrm{a}}$ \\
Total Kjeldhal nitrogen $(\mathrm{mg} / \mathrm{L})$ & $3.88-26.02$ & $147-233^{\mathrm{b}}$ \\
Phosphorus $(\mathrm{mg} / \mathrm{L})$ & $22.97-57.04$ & $33-128^{\mathrm{b}}$ \\
\hline
\end{tabular}

aSaddoud and Sayadi, 2007; 'bel Nery et al., 2007.

\section{Operational setup}

The reactors were operated in a semi-continuous regimen with initial and final organic loads of 173.3 and $994.8 \mathrm{mg} \mathrm{O}_{2} \cdot \mathrm{L}^{-1} \cdot \mathrm{d}^{-1}$, respectively. The reactors were operated at room temperature $\left(14^{\circ}-29^{\circ} \mathrm{C}\right)$ and with hydraulic retention times (HRTs) of $20,18,14,10,8,6,5,4,3$, $2,1.5$, and 1 day.

\section{Analytical methods}

Samples were taken daily to measure $\mathrm{pH}$, alkalinity, volatile acidity, total solids (TS), volatile solids (VS), chemical oxygen demand (COD), and total Kjeldhal nitrogen (TKN) according to standard methods (APHA, 1998). 


\section{Statistical analysis}

The data obtained were subjected to analysis of variance, and the averages were compared by the Tukey test using the Statistica 7.0 (2004) software (StatSoft Inc, Tulsa, OK, USA).

\section{DNA extraction and quantification}

To evaluate the effect of different support media on the microbial community, the DNA of the reactors' biomass (Reactors A, B, and C) was extracted during the final of the start-up phase (1 day HRT) using a commercial kit (PSP Spin Stool DNA Kit, Invitek Inc., Hayward, CA, USA) following supplier instructions up to step 3 and consecutive treatment with phenol/ chloroform and ethanol precipitation. The DNA integrity was determined by electrophoresis on 1X TAE (Tris, acetic acid, and ethylenediamine tetraacetic acid) $0.8 \%$ agarose gels and staining with $0.5 \mu \mathrm{g} / \mathrm{mL}$ ethidium bromide. The purity of DNA was estimated spectrophotometrically.

\section{Polymerase chain reaction (PCR) amplification}

Bacterial and archaeal $16 \mathrm{~S} r R N A$ genes were amplified from $50 \mathrm{ng}$ total reactor DNA by PCR. Prior to the PCR, samples were incubated with $0.6 \mu \mathrm{g}$ BSA per ng DNA in a total volume of $11 \mu \mathrm{L}$ for $45 \mathrm{~min}$ at $37^{\circ} \mathrm{C}$ to scavenge PCR-inhibiting substances. The reaction contained 1X PCR buffer (Invitrogen), $0.2 \mu \mathrm{M}$ of each primer, $2 \mathrm{mM} \mathrm{MgCl}_{2}, 0.2 \mathrm{mM}$ dNTP (Invitrogen), $0.3 \mu \mathrm{g} \mathrm{BSA}$, and $1 \mathrm{U}$ Taq DNA polymerase (Invitrogen) in a final volume of 50 $\mu \mathrm{L}$. Amplifications were performed in a Mastercycler gradient thermocycler (Eppendorf).

The primers 27F (5'-AGAGTTTGATCMTGGCTCAG-3') and 1492R (5'-GGTTACC TTGTTACGACTT-3') were used to amplify bacterial $16 S$ rRNA (Lane, 1991). To amplify the archaeal $16 \mathrm{~S} r R N A$ genes, primer $27 \mathrm{~F}$ was replaced by $28 \mathrm{~F}$ (5'-TGGTTGATCCTGCCAG AGG-3') (Shigematsu et al., 2006). The PCR conditions were: 3 min at $95^{\circ} \mathrm{C} ; 25$ cycles of 45 $\mathrm{s}$ at $95^{\circ} \mathrm{C}, 45 \mathrm{~s}$ at $55^{\circ} \mathrm{C}$, and $1.5 \mathrm{~min}$ at $72^{\circ} \mathrm{C}$; and a final extension for $10 \mathrm{~min}$ at $72^{\circ} \mathrm{C}$.

\section{$16 S r R N A$ gene cloning, amplified ribosomal DNA restriction analysis, and sequencing}

Approximately $75 \mathrm{ng}$ amplicons were ligated to $50 \mathrm{ng}$ pGEM-T easy vector (Promega) according to manufacturer instructions. The ligation product was transformed into Escherichia coli DH5 $\alpha$ competent cells. Two libraries of 96 clones were constructed for each reactor, one to the Bacteria domain $(\mathrm{BacA}, \mathrm{BacB}$, and $\mathrm{BacC})$ and another to the Archaea domain (ArcA, ArcB, and ArcC). Plasmids were extracted by the alkaline lysis method in 96-well plates, and the DNA was digested with the restriction enzymes HaeIII, HinfI, and Rsal (Moyer et al., 1996). Clones with unique restriction patterns were sequenced according the ET terminator mix (GE Healthcare) instructions. Sequencing was performed using an ABI 377 DNA sequencer (Applied Biosystems). Reads were trimmed to remove low quality bases using the Phred program (Ewing et al., 1998).

\section{Sequence analyses}

$16 S$ rRNA gene sequences were aligned, edited, and analyzed as described by Etto 
et al. (2012) using the Gblock program (Castresana, 2000), the RDP tools (release 10) (Cole et al., 2009), and the Mothur software package version 1.13 (Schloss et al., 2009). Chimeras, if detected, were removed with Chimera Check or Pintail using the Greengenes database for Bacteria and Silva database for Archaea as templates. The sequences of the $16 \mathrm{~S} r R N A$ spanning the V2-V3 region with an average length of $500 \mathrm{bp}$ were deposited in the GenBank database under the accession No. JN394589-JN394653 (archaeal sequences) and JN809472JN809647 (bacterial sequences). Sequences were clustered into operational taxonomic units (OTUs; identity $\geq 97 \%$ ). The similarity in the composition of the clone libraries was examined by the $\int$-LibShuff program (Schloss et al., 2004).

\section{RESULTS AND DISCUSSION}

\section{Performance of the wastewater treatment system}

Reactors A, B, and C, containing polypropylene rings, polyurethane foam cubes, and clay brick pieces as support material, respectively, were constructed and filled with slaughterhouse wastewater substrate. The ratio of volatile acidity/alkalinity was below 0.13 during most HRT evaluations, indicating a sufficient buffering capacity inside the reactors (Figure 1). When the organic loading rates were increased by reducing the HRT from 3 to 2, variations of this ratio reached a peak of 0.68 in reactor A, 0.55 in B and 0.62 in C. In anaerobic digestion, a delicate balance exists between the primary processes (hydrolysis and acidogenesis) and the conversion of the acid products by acetogenic and methanogenic microorganisms into methane and carbon dioxide (Cohen et al., 1982). Variations in flow and organic matter concentration may adversely affect the efficiency of an anaerobic reactor (Leitão et al., 2006). The volatile fatty acid accumulation can be a response to overload, sudden changes in HRT and organic rates, and reactor temperature (Leitão et al., 2006).

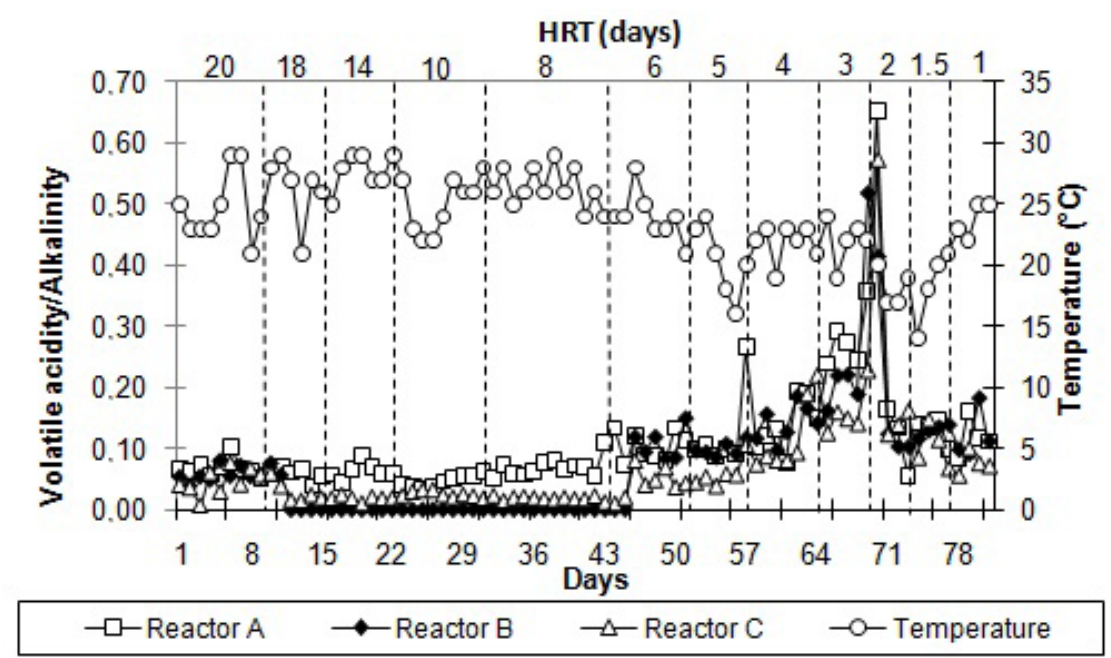

Figure 1. Volatile acidity/alkalinity of treated wastewater by reactors A, B, and C, which were filled with rings of polypropylene, polyurethane foam, and pieces of clay brick, respectively, plotted against temperature and hydraulic retention time (HRT). 
The wastewater organic matter content was measured indirectly by the COD removal of the reactors (Figure 2). During the stepwise increase of organic loading rate, COD removal efficiencies increased gradually. At the beginning of the analysis, in an HRT of 20 days, reactor A showed a lower level of COD removal than reactors B and C. However, with an HRT of 18 , the COD removal of reactor A reached the COD levels of $\mathrm{B}$ and $\mathrm{C}$, and all reactors maintained their levels around $90 \%$ until the HRT of 4 . From that, the COD rate removal of reactors $\mathrm{B}$ and $\mathrm{C}$ decreased gradually, reaching $67 \%$ at the $1.5 \mathrm{HRT}$, while the rate of reactor A decreased deeply to values close to $50 \%$. The lower efficiency registered from the HRTs of 4 to 1.5 could be because of the short contact time between biomass and substrate (Lettinga et al., 1997). At 1 day HRT, all reactors partially recover their COD removal, maintaining similar values around $65-80 \%$. Silva et al. (2006) also showed that the support medium influences the COD removal. While more than $85 \%$ COD removal were reached in reactors with foam, vegetal carbon, and alumina-based ceramics after 7 days of operation, reactors filed with polyethylene needed more than 14 days of operation to reach these values (Silva et al., 2006).

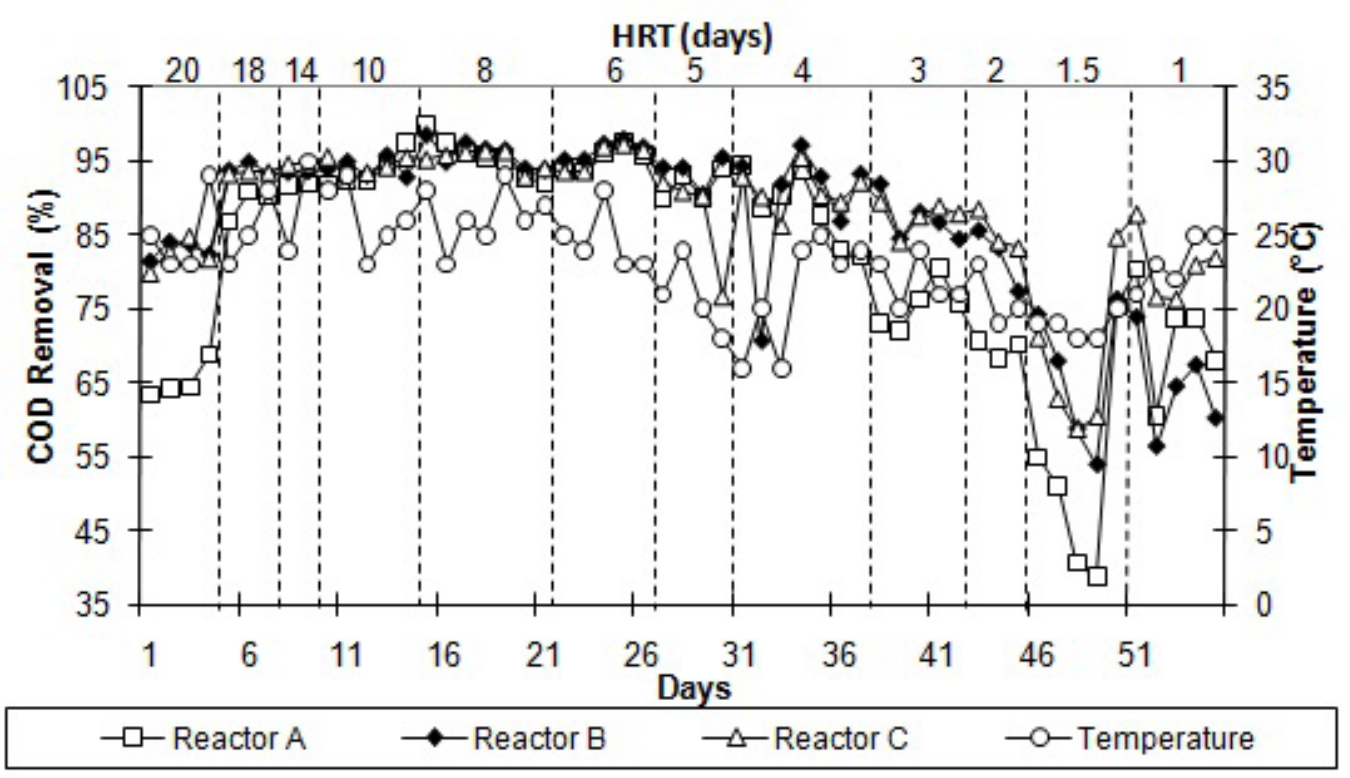

Figure 2. Chemical oxygen demand (COD) removal of wastewater treated by reactors $\mathrm{A}, \mathrm{B}$, and $\mathrm{C}$, which were filled with rings of polypropylene, polyurethane foam, and pieces of clay brick, respectively, plotted against temperature and hydraulic retention time (HRT).

The production of a final effluent of at least $87.6 \mathrm{mg}$ COD/L for HTRs between 20 and 3 days indicated a general high-quality COD removal. At lower HTRs, these values dropped to $69.8 \mathrm{mg} \mathrm{COD} / \mathrm{L}$. This agrees with the literature, which shows that COD removal efficiencies increase with the time of operation (Del Pozo et al., 2003).

The three reactors showed very similar profiles of TS and VS removal, reaching rates of $60 \%$ TS average removal and $75 \%$ VS average removal (Figure S1). The solid concentration is known as the total residue present on the substrate either from organic or inorganic 
material, and it is an indicator of the total mass to be treated. The detection of solids, especially VS, indicates the presence of organic matter in the wastewater (Leite and Povinelli, 1999).

Despite the effluent of reactor $\mathrm{B}$ had the highest $\mathrm{pH}$ value at the beginning of the experiment, it turned out to be equivalent to the values of reactors A and C in an HRT of 18 . Up to the HRT of 8, the $\mathrm{pH}$ value of the effluent of the three reactors gradually decreased and then remained almost constant (Figure S2). Massé and Masse (2001) also detected a similar profile. $\mathrm{pH}$ dropping in the bioreactor system, especially in anaerobic microenvironments, is considered to be an index of volatile fatty acid (VFA) production in a system with buffering capacity. VFA production is always associated with the conversion of the organic fraction to acid intermediates in the anaerobic microenvironment by specific groups of bacteria (Mohan et al., 2007).

High TKN removal was observed in all three reactors during most of the monitoring time (Figure 3). Based on Tal et al. (2006), this nitrogen removal may have been achieved by nitrification (aerobic) followed by denitrification (anaerobic) and/or anaerobic ammonium oxidation (ANAMMOX). Despite the volatile acidity/alkalinity ratio, COD and TKN removal unbalance registered in 2 and 1.5 days HRT; the lower values of volatile acidity/alkalinity that were observed later, in the 1 day HRT, indicated that the process stabilized again.

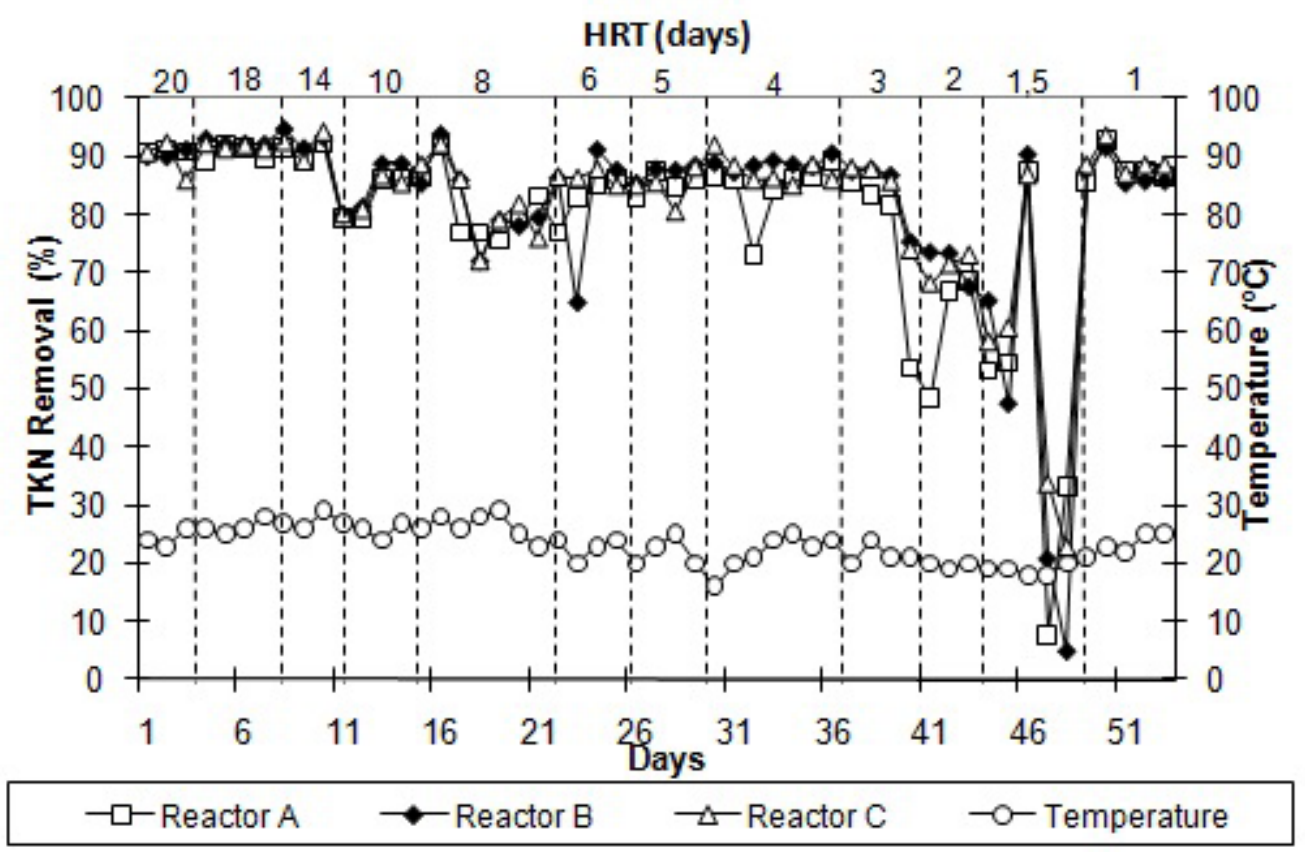

Figure 3. Total Kjeldhal nitrogen (TKN) removal of treated wastewater by reactors A, B, and C, which were filled with rings of polypropylene, polyurethane foam, and pieces of clay brick, respectively, plotted against temperature and hydraulic retention time (HRT).

The physicochemical analysis of the reactor systems tested suggested their feasibility, with rates of COD removal of $72 \pm 8 \%$ at HRTs of 1 day. Despite the fact that the three 
different support media generated similar UAF reactor physicochemical performance, their influence on the composition of the prokaryotic groups was also investigated.

\section{Microbial communities of the anaerobic reactors}

The major bacterial and archaeal groups present in the three UAF reactors were determined by restriction patterns and $16 S$ rRNA gene sequencing analysis. The 200 bacterial clones were classified into 11 different phyla (Figure 4). About $27 \%$ was assigned to Proteobacteria with a predominance of Deltaproteobacteria (77.6\%). Bacteroidetes (17.1\%) and Firmicutes $(10.9 \%)$ phyla were also frequently found. Acidobacteria, Actinobacteria, and Caldiserica were found only in reactor A, whereas Lentisphaerae and Chlorobi were found only in reactors $\mathrm{B}$ and $\mathrm{C}$, respectively.

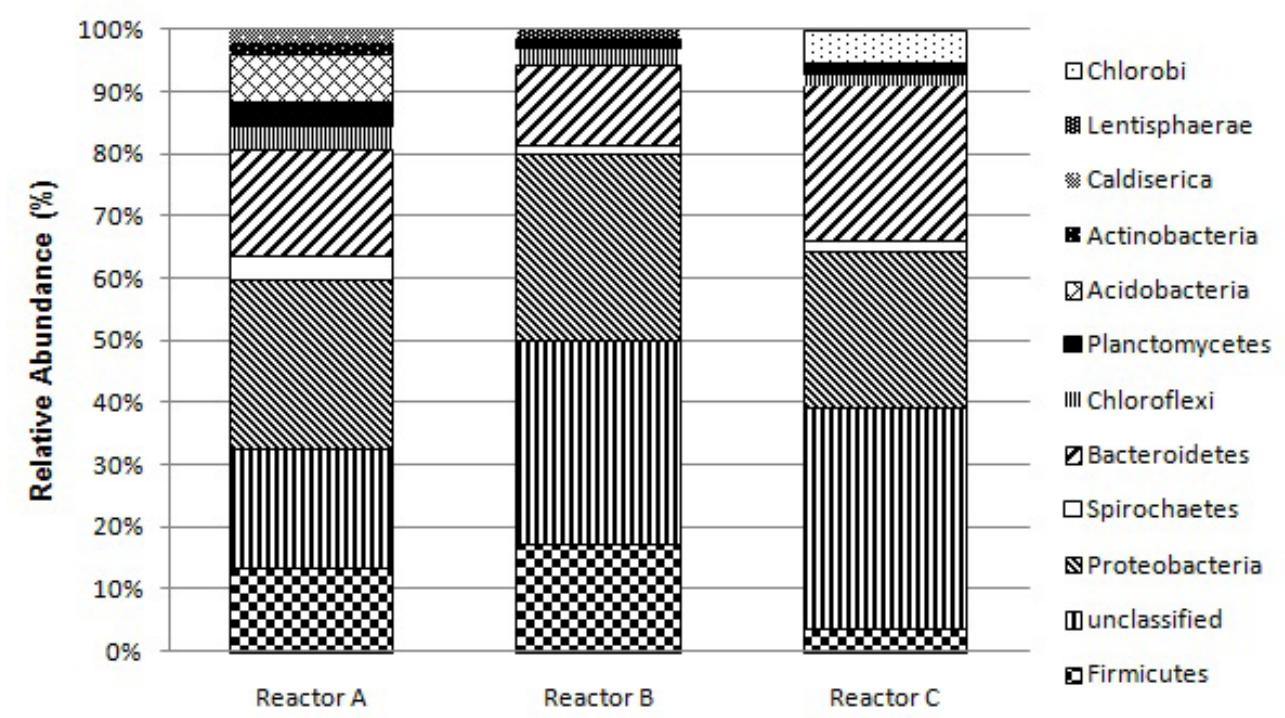

Figure 4. Bacterial composition from upflow anaerobic filters. Clones were identified using the Ribosomal Database Project II. Sequences showing less than $80 \%$ confidence to known bacterial phylogenetic groups were listed as unclassified.

Deltaproteobacteria use mainly low-molecular-weight organic matter, such as acetic acid and amino acids (Rivière et al., 2009). Bacteroidetes are known to be proteolytic bacteria (Kindaichi et al., 2004), which degrade proteins and then ferment the amino acids to acetate (Rivière et al., 2009). Firmicutes are syntrophic bacteria, which can degrade VFAs such as butyrate and its analogs. The products are then degraded by hydrogenotrophic methanogens producing $\mathrm{H}_{2}$ (Rivière et al., 2009).

Chlorobi, Lentisphaerae, and Planctomycetes were also found in smaller groups in anaerobic sludge digesters by Rivière et al. (2009). The Chloroflexi phylum ribotypes are a common fermenting group described in anaerobic reactors (Rivière et al., 2009). Caldiserica are anaerobic and able to reduce compounds containing sulfur (thiosulfate, sulfite, and elemental 
sulfur) (Mori et al., 2009). Actinobacteria have polyphosphate-accumulating capability, and the wastewater treatment industry has used them for phosphorus removal (Kong et al., 2005). Acidobacteria were reported to be involved in degrading and hydrolyzing some organic compounds under microaerophilic conditions to produce acids, and they form syntrophic associations with hydrogenotrophic methanogens (Fang et al., 2002).

The ANAMMOX process is performed by autotrophic bacteria that are members of the order Planctomycetales (Tal et al., 2006), which were found in the three reactors (Figure 4).

The 169 archaeal clones were classified into 2 phyla: Euryarchaeota $(89.3 \%)$ and Crenarchaeota (10.7\%). Methanomicrobiales and Methanosarcinales were the predominant groups in all reactors (Figure 5).

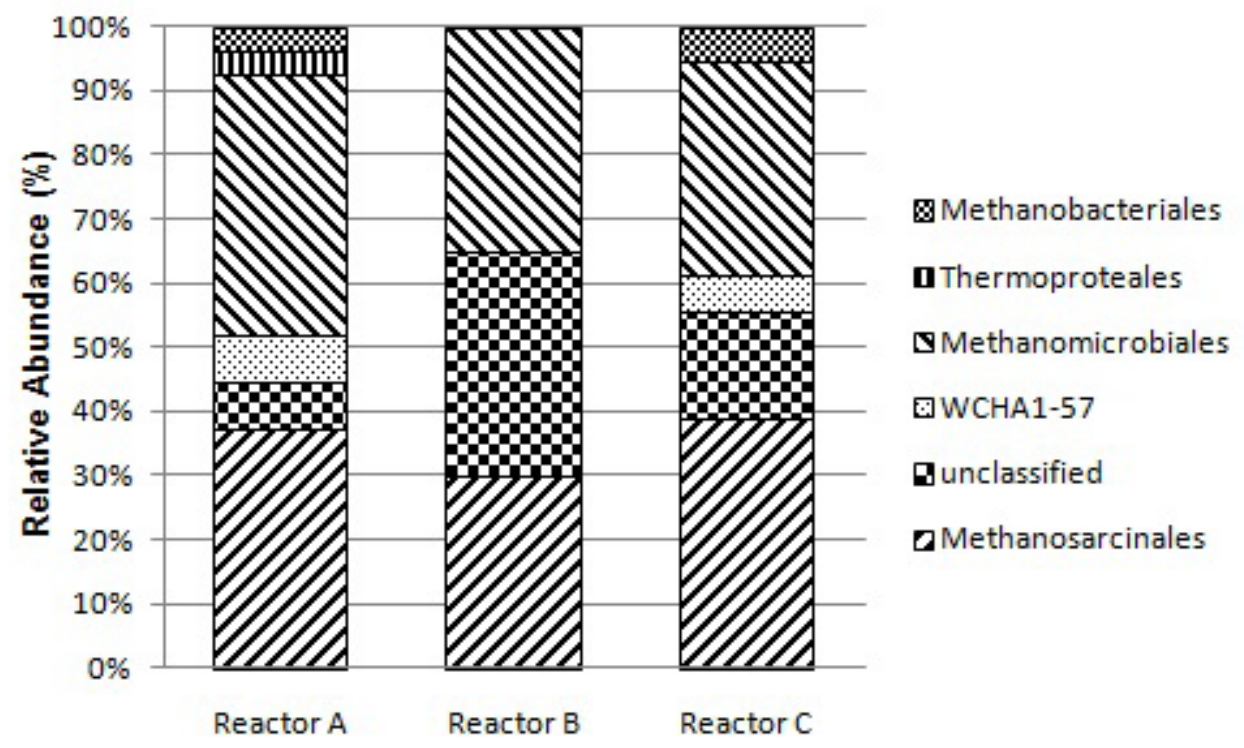

Figure 5. Archaeal composition from upflow anaerobic filters. Clones were identified using the Silva Database. Sequences showing less than $80 \%$ confidence to known archaeal phylogenetic groups were listed as unclassified.

Methanogens are active at the end of the anaerobic food chain and are specialized in the degradation of a very limited number of substrates. Genera within Methanomicrobiales and Methanobacteriales are hydrogenotrophic methanogens (Demirel and Scherer, 2008; Fernández et al., 2008). Other groups that were represented in the three reactors included Methanosarcinales, which are acetoclastic methanogens (Fernández et al., 2008).

Hydrogenotrophic methanogens utilize only $\mathrm{H}_{2} / \mathrm{CO}_{2}$ (Demirel and Scherer, 2008; Fernández et al., 2008). Acetoclastic Methanosaeta spp (Huser et al., 1982) only use acetate. The most versatile methanogens are Methanosarcina spp, which can use $\mathrm{H}_{2} / \mathrm{CO}_{2}$, acetate, methanol, methylated amines, and pyruvate (Lyimo et al., 2000).

Thermoplasma are thermoacidophilic archaea (Zillig et al., 1981); they are strictly anaerobic heterotrophs that are dependent on the reduction of sulfur to $\mathrm{H}_{2} \mathrm{~S}$ for optimal growth (Jongsareejit, 2004). This group was found in studies of animal waste (Xia et al., 2012) and municipal solid waste anaerobic reactors (Cardinali-Rezende et al., 2012). 
WCHA1-57 was already found in an aquifer contaminated with hydrocarbons and chlorinated solvents undergoing intrinsic bioremediation, but it was never reported in anaerobic reactors (Dojka et al., 1998). Nevertheless, most prokaryotes identified in this study agree with the microbial communities found in other anaerobic digesters that generally are dominated by Deltaproteobacteria, Firmicutes, Chloroflexi, Spirochaetes, Bacteroidetes, Methanomicrobia, Methanobacteria, and Thermoplasmata (Rivière et al., 2009).

The $\int$-Libshuff analysis showed a similar microbial composition among the three reactors, with a $\mathrm{P}$ value $>0.00833$ (Bonferroni's correction). This result may support the similar performance of the three reactors in terms of $\mathrm{pH}$, TS, VS, and TKN removal. Despite the similarities among the reactors, Chao and Shannon indices (Table 3) showed that reactors B and C presented the highest richness and diversity of Bacteria, and reactor $\mathrm{C}$ had the highest values for Archaea. Changes in the species composition of a microbial population modify methanogenic activity because each methanogenic group has its own specific activity, which directly affects the performance of an anaerobic reactor (Ince et al., 2001).

Table 3. Prokaryotic richness and diversity of the anaerobic reactors.
\begin{tabular}{lccccccc}
\hline Reactor & Bacteria domain & & & Archaea domain \\
\cline { 2 - 4 } & OTU & Chao & Shannon & & OTU & Chao & Shannon \\
\hline A & 34 & 59 & 3.38 & 12 & 30 & 2.03 \\
B & 51 & 129 & 3.82 & 10 & 31 & 2.02 \\
C & 47 & 158 & 3.80 & 13 & 68 & 2.45 \\
\hline
\end{tabular}

The number and the abundance of operational taxonomic units (OTUs) from each reactor were calculated using the Mothur program (Schloss et al., 2009).

The presence of many unclassified OTUs show that the anaerobic digesters are specific ecosystems that contain microorganisms that are not found in any other environment and are therefore hard to affiliate (Rivière et al., 2009).

\section{CONCLUSIONS}

The physicochemical analysis of the tested UAF systems suggested their feasibility, with rates of COD removal of $72 \pm 8 \%$ at an HRT of 1 day. Analysis of $\mathrm{pH}$, alkalinity, volatile acidity, TS, total VS, and nitrogen indicated similar performances among the three support media tested. Proteobacteria, Methanomicrobiales, and Methanosarcinales were the predominant groups found in the reactors. Despite the prokaryotic community similarities among the reactors, pieces of clay brick as the support medium contained more diverse and abundant bacterial and archaeal populations than other support media.

\section{ACKNOWLEDGMENTS}

We would like to thank Prof. Dr. Emanuel Maltempi de Souza for his critical reading and new insights into the manuscript. We also thank Valter Baura, Roseli Prado, Dannianni Zardo, and Denise Mendes for their technical assistance. Research supported by CAPES, National Institute of Science and Technology on Biological Nitrogen Fixation (INCT-FBN/ CNPq-MCT), and Fundação Araucária. 


\section{Supplementary material}

\section{REFERENCES}

APHA (1998). Standard Methods for the Examination of Water and Wastewater. 20th edn. APHA/AWWA, Washington. Beux S, Nunes E and Barana AC (2007). Effect of temperature on two-phase anaerobic reactors treating slaughterhouse wastewater. Braz. Arch. Biol. Technol. 50: 1061-1072.

Cardinali-Rezende J, Colturato LF, Colturato TD, Chartone-Souza E, et al. (2012). Prokaryotic diversity and dynamics in a full-scale municipal solid waste anaerobic reactor from start-up to steady-state conditions. Bioresour. Technol. 119: 373-383.

Castresana J (2000). Selection of conserved blocks from multiple alignments for their use in phylogenetic analysis. Mol. Biol. Evol. 17: 540-552.

Cohen A, Breure AM, van Andel JG and van Deursen A (1982). Influence of phase separation on the anaerobic digestion of glucose-II: stability, and kinetic responses to shock loadings. Wat. Res. 16: 449-455.

Cole JR, Wang Q, Cardenas E, Fish J, et al. (2009). The Ribosomal Database Project: improved alignments and new tools for rRNA analysis. Nucleic Acids Res. 37: D141-D145.

Del Nery V, De Nardi IR, Damianovic MHRZ, Pozzi E, et al. (2007). Long-term operating performance of a poultry slaughterhouse wastewater treatment plant. Res. Conserv. Recycling 50: 102-114.

Del Pozo R, Tas DO, Dulkadiroğlu H and Orhon D (2003). Biodegradability of slaughterhouse wastewater with high blood content under anaerobic and aerobic conditions. J. Chem. Technol. Biotechnol. 78: 384-391.

Demirel B and Scherer P (2008). The roles of acetotrophic and hydrogenotrophic methanogens during anaerobic conversion of biomass to methane: a review. Rev. Environ. Sci. Biotechnol. 7: 173-190.

Dojka MA, Hugenholtz P, Haack SK and Pace NR (1998). Microbial diversity in a hydrocarbon- and chlorinated-solventcontaminated aquifer undergoing intrinsic bioremediation. Appl. Environ. Microbiol. 64: 3869-3877.

Etto RM, Cruz LM, Jesus EC, Galvão CW, et al. (2012). Prokaryotic communities of acidic peatlands from the southern Brazilian Atlantic Forest. Braz. J. Microbiol. 43: 661-674.

Ewing B, Hillier L, Wendl MC and Green P (1998). Base-calling of automated sequencer traces using phred. I. Accuracy assessment. Genome Res. 8: 175-185.

Fang HH, Liu H and Zhang T (2002). Characterization of a hydrogen-producing granular sludge. Biotechnol. Bioeng. 78: 44-52.

Fernández N, Díaz EE, Amils R and Sanz JL (2008). Analysis of microbial community during biofilm development in an anaerobic wastewater treatment reactor. Microb. Ecol. 56: 121-132.

Huser BA, Wuhrmann K and Zehnder AJB (1982). Methanothrix soehngenii gen. nov. sp. nov., a new acetotrophic nonhydrogen-oxidizing methane bacterium. Arch. Microbiol. 132: 1-9.

Ince O, Kasapgil B and Yenigun O (2001). Determination of potential methane production capacity of a granular sludge from a pilot-scale upflow anaerobic sludge blanket reactor using a specific methanogenic activity test. J. Chem. Technol. Biot. 76: 573-578.

Jongsareejit B (2004). Hyperthermophilic Archaea. Silpakorn Univ. Int. J. 4: 166-179.

Kindaichi T, Ito T and Okabe S (2004). Ecophysiological interaction between nitrifying bacteria and heterotrophic bacteria in autotrophic nitrifying biofilms as determined by microautoradiography-fluorescence in situ hybridization. Appl. Environ. Microbiol. 70: 1641-1650.

Kong Y, Nielsen JL and Nielsen PH (2005). Identity and ecophysiology of uncultured actinobacterial polyphosphateaccumulating organisms in full-scale enhanced biological phosphorus removal plants. Appl. Environ. Microbiol. 71 : 4076-4085.

Lane DJ (1991). 16S/23S rRNA Sequencing. In: Bacterial Systematics (Stackebrandt E and Goodfellow M, eds.). Wiley, New York.

Lee C, Kim J, Shin SG and Hwang S (2008). Monitoring bacterial and archaeal community shifts in a mesophilic anaerobic batch reactor treating a high-strength organic wastewater. FEMS Microbiol. Ecol. 65: 544-554.

Leitão RC, Van Haandel AC, Zeeman G and Lettinga G (2006). The effects of operational and environmental variations on anaerobic wastewater treatment systems: a review. Bioresour. Technol. 97: 1105-1118.

Leite VD and Povinelli J (1999). Comportamento dos sólidos totais no processo de digestão anaeróbia de resíduos sólidos urbanos e industriais. Rev. Bras. Eng. Agr. Amb. 3: 229-232.

Lettinga G, Field J, van Lier J and Zeeman G (1997). Advanced anaerobic wastewater treatment in the near future. Water Sci. Technol. 35: 5-12. 
Lyimo TJ, Pol A, Op den Camp HJ, Harhangi HR, et al. (2000). Methanosarcina semesiae sp. nov., a dimethylsulfideutilizing methanogen from mangrove sediment. Int. J. Syst. Evol. Microbiol. 50: 171-178.

Massé DI and Masse L (2001). The effect of temperature on slaughterhouse wastewater treatment in anaerobic sequencing batch reactors. Bioresour. Technol. 76: 91-98.

Merzouki M, Bernet N, Delgenés JP and Benlemlih M (2005). Effect of prefermentation on denitrifying phosphorus removal in slaughterhouse wastewater. Bioresour. Technol. 96: 1317-1322.

Mohan SV, Babu VL and Sarma PN (2007). Anaerobic biohydrogen production from dairy wastewater treatment in sequencing batch reactor (AnSBR): effect of organic loading rate. Enzyme Microb. Technol. 41: 506-515.

Mori K, Yamaguchi K, Sakiyama Y, Urabe T, et al. (2009). Caldisericum exile gen. nov., sp. nov., an anaerobic, thermophilic, filamentous bacterium of a novel bacterial phylum, Caldiserica phyl. nov., originally called the candidate phylum OP5, and description of Caldisericaceae fam. nov., Caldisericales ord. nov. and Caldisericia classis nov. Int. J. Syst. Evol. Microbiol. 59: 2894-2898.

Moyer CL, Tiedje JM, Dobbs FC and Karl DM (1996). A computer-simulated restriction fragment length polymorphism analysis of bacterial small-subunit rRNA genes: efficacy of selected tetrameric restriction enzymes for studies of microbial diversity in nature. Appl. Environ. Microbiol. 62: 2501-2507.

Rivière D, Desvignes V, Pelletier E, Chaussonnerie S, et al. (2009). Towards the definition of a core of microorganisms involved in anaerobic digestion of sludge. ISME J. 3: 700-714.

Rodriguez RP and Zaiat M (2011). Influence of carbon source and inoculum type on anaerobic biomass adhesion on polyurethane foam in reactors fed with acid mine drainage. Bioresour. Technol. 102: 5060-5065.

Saddoud A and Sayadi S (2007). Application of acidogenic fixed-bed reactor prior to anaerobic membrane bioreactor for sustainable slaughterhouse wastewater treatment. J. Hazard Mater. 149: 700-706.

Schloss PD, Larget BR and Handelsman J (2004). Integration of microbial ecology and statistics: a test to compare gene libraries. Appl. Environ. Microbiol. 70: 5485-5492.

Schloss PD, Westcott SL, Ryabin T, Hall JR, et al. (2009). Introducing mothur: open-source, platform-independent, community-supported software for describing and comparing microbial communities. Appl. Environ. Microbiol. 75: 7537-7541.

Shigematsu T, Tang Y, Mizuno Y, Kawaguchi H, et al. (2006). Microbial diversity of mesophilic methanogenic consortium that can degrade long-chain fatty acids in chemostat cultivation. J. Biosci. Bioeng. 102: 535-544.

Silva AJ, Hirasawa JS, Varesche MB, Foresti E, et al. (2006). Evaluation of support materials for the immobilization of sulfate-reducing bacteria and methanogenic archaea. Anaerobe 12: 93-98.

Tal Y, Watts JE and Schreier HJ (2006). Anaerobic ammonium-oxidizing (anammox) bacteria and associated activity in fixed-film biofilters of a marine recirculating aquaculture system. Appl. Environ. Microbiol. 72: 2896-2904.

Tang YQ, Fujimura Y, Shigematsu T, Morimura S, et al. (2007). Anaerobic treatment performance and microbial population of thermophilic upflow anaerobic filter reactor treating awamori distillery wastewater. J. Biosci. Bioeng. 104: 281-287.

Tay J and Show K (1998). Media-induced hydraulic behavior and performance of upflow filters. J. Environ. Eng. 124: 720-729.

Xia Y, Massé DI, McAllister TA, Kong Y, et al. (2012). Identity and diversity of archaeal communities during anaerobic co-digestion of chicken feathers and other animal wastes. Bioresour. Technol. 110: 111-119.

Zillig W, Tu J and Holz I (1981). Thermoproteales-a third order of thermoacidophilic archaebacteria. Nature 293: 85-86. 